\author{
Monika Przybylska*
}

\title{
ZAKRES OCHRONY \\ BEZPIECZEŃSTWA ENERGETYCZNEGO W SEKTORZE ŹRÓDEŁ ENERGII ODNAWIALNEJ W KONTEKŚCIE „MAŁEGO TRÓJPAKU ENERGETYCZNEGO”
}

\section{Uwagi ogólne}

Bezpieczeństwo energetyczne - rozumiane ogólnie jako gwarancja dostaw energii elektrycznej - jest jednym z ważniejszych dóbr chronionych przez prawo przyjmowane na trzech szczeblach: międzynarodowym, europejskim i krajowym ${ }^{1}$. Kontekst prawny regulacji przyjmowanych w tym zakresie wskazuje, że bezpieczeństwo energetyczne jest wartością chronioną w sposób bezpośredni (przez prawo energetyczne) ${ }^{2}$ oraz pośredni (głównie przez prawo ochrony środowiska). Ponadto analiza przepisów prawa energetycznego prowadzi do wniosku, że istota bezpieczeństwa energetycznego zapewniona jest nie tylko poprzez wytwarzanie odpowiedniej ilość energii ze źródeł tradycyjnych, ale przede również ze źródeł odnawialnych. Ten ostatni aspekt jest wartością chronioną prawnie głównie przez prawo europejskie. Podstawowe zasady zmierzające do zapewnienia bezpieczeństwa energetycznego poprzez wytwarzanie i dostarczanie energii pochodzącej ze źródeł odnawialnych przyjęte zostały w dyrektywie Parlamentu Europejskiego i Rady 2009/28/WE z dnia 23 kwietnia 2009 r. w sprawie promowania stosowania energii ze źródeł odnawialnych zmieniająca i w następstwie uchylająca dyrektywy 2001/77/WE oraz 2003/30/WE3 (dalej: dyrektywa OZE, dyrektywa 2009/28).

* Dr, Instytut Nauk Ekonomicznych i Społecznych, Wydział Przyrodniczo-Technologiczny Uniwersytetu Przyrodniczego we Wrocławiu.

1 Zgodnie ustawą z dnia 10 kwietnia 1997 r. Prawo energetyczne (tekst jedn. Dz. U. z 2012 r., poz. 1059 z późn. zm.) art. 3 pkt 16 bezpieczeństwo energetyczne to „stan gospodarki umożliwiający pokrycie bieżącego i perspektywicznego zapotrzebowania odbiorców na paliwa i energię w sposób technicznie i ekonomicznie uzasadniony, przy zachowaniu wymagań ochrony środowiska”.

${ }_{2}$ Rozumiane jako zbiór unijnych i krajowych przepisów dotyczących funkcjonowania rynku elektroenergetycznego.

${ }_{3}$ Dz. Urz. UE L 140/16. 
Przyjmuje się, patrząc całościowo na dyrektywę OZE, że w zakresie warunków materialnych implementacji tej dyrektywy państwa członkowskie powinny przyjąć odpowiednie przepisy krajowe w zakresie:

1) zwiększenia bezpieczeństwa energetycznego poprzez zmniejszenie zależności państw członkowskich Unii Europejskiej od importu energii;

2) dążenia do zdecentralizowanego wytwarzania energii, które poprzez korzystanie z lokalnych źródeł energii będzie skutkowało większym bezpieczeństwem dostaw energii w skali lokalnej, krótszych odległościach transportowych oraz zmniejszeniem strat przesyłowych;

3) tworzenie możliwości zatrudnienia i rozwoju regionalnego, zwłaszcza na obszarach wiejskich;

4) wspieranie rozwoju technologicznego i innowacji oraz

5) obniżenie emisji gazów cieplarnianych, co pozwoli zrealizować postanowienia protokołu z Kioto przez całą UE.

W kontekście najważniejszych działań państw członkowskich UE zmierzających do przyjęcia dyrektywy OZE Polska uchybiła obowiązkowi implementacji, którego termin upłyną 5 grudnia $2010 \mathrm{r}^{4}$., nie dokonała bowiem całkowitej implementacji polegającej na przyjęciu odpowiednich regulacji zmierzających do osiągnięcia na poziomie krajowym celów dyrektywy OZE. Nie wynika to wyłącznie z tego, że nie została uchwalona ustawa o odnawialnych źródłach energii (jako cześć tzw. trójpaku energetycznego), ale również dlatego, że nie ma porozumienia (polityczno-prawnego) co do kształtu tej ustawy w zakresie promocji poszczególnych źródeł energii odnawialnej. Niemniej wyrazem normatywnym częściowej implementacji dyrektywy OZE jest ostatnia nowelizacja ustawy Prawo energetyczne, czyli tak zwany „mały trójpak energetyczny”. Równocześnie władze krajowe, odpowiedzialne za implementacje unijnych dyrektyw, podejmują nieprzerwane działania zmierzające do przyjęcia odrębnej ustawy o $\mathrm{OZE}^{6}$. Czekając na pełną i prawidłową implementację przepisów dyrektywy 2009/28 warto postawić pytanie o zakres ochrony bezpieczeństwa energetycznego poprzez produkcję energii z OZE uregulowany „małym trójpakiem energetycznym”. Wskazując na zakres tematyczny podjętego zagadnienia trzeba podkreślić, że przedmiotem analizy jest ocena rozwiązań prawnych służących promocji i rozwojowi OZE w Polsce.

${ }^{4}$ Art. 27 dyrektywy OZE.

${ }_{5}^{5}$ Ustawa z dnia 26 lipca 2013 r. o zmianie ustawy - Prawo energetyczne oraz niektórych innych ustaw (Dz. U. z 2013 r., poz. 984), która weszła w życie 11 września 2013 r.

${ }_{6}^{6}$ Ostatni projekt ustawy o OZE pochodzi z listopada $2013 \mathrm{r}$.

7 Pełna i prawidłowa implementacja dyrektywy OZE jest niezbędna z uwagi na wszczęte w marcu 2013 r. przez Komisje Europejską postępowanie przed Trybunałem Sprawiedliwości Unii Europejskiej przeciwko Polsce $\mathrm{z}$ tytułu nieprzestrzegania prawa unijnego. Zob. komunikat prasowy Komisji Europejskiej z 21 marca 2013 r. http://europa.eu/rapid/press-release_IP-13-259_pl.htm (odczyt 10.12.2013). 
Ostatnia nowelizacja ustawy - Prawo energetycznego (,mały trójpak energetyczny”), powoduje konieczność wyróżnienia „tradycyjnych” instrumentów prawnych wspierających rozwój energii odnawialnej (obowiązujących przed wejściem w życie „małego trójpaku energetycznego”), do których zaliczamy przede wszystkim regulacje dotyczące wsparcia bezpośredniego oraz „nowych”, do których można zaliczyć głównie: 1) rozwiązania w zakresie wspierania energetyki prosumenckiej, 2) regulacje dotyczące wydawania gwarancji pochodzenia energii elektrycznej wytwarzanej w odnawialnym źródle energii, 3) krajowy plan działania w zakresie energii ze źródeł odnawialnych oraz 4) zasady współpracy międzynarodowej w zakresie wspólnych projektów inwestycyjnych oraz współpracy międzynarodowej w zakresie odnawialnych źródeł energii. $Z$ wymienionych instrumentów prawnych analiza dotyczyła będzie jedynie przyjętych rozwiązań w zakresie energetyki prosumenckiej. Ponadto, poza zakresem analizy niniejszego artykułu znajduje się również ocena ochrony bezpieczeństwa energetycznego w formach wsparcia pośredniego, regulowana innymi przepisami niż ustawa - Prawo energetyczne, których głównym celem jest wspieranie decyzji o podjęciu inwestycji w źródła odnawialne. Do tej grupy instrumentów należą m.in. fiskalne formy wsparcia, których celem jest obniżenie kosztów inwestycji poprzez korzystne dla wytwórcy rozporządzenie wysokością zwłaszcza stawki podatku VAT, podatku dochodowego, podatku od nieruchomości oraz akcyzą, a także różnego rodzaju dotacje, którymi rozporządzają kompetentne podmioty publiczne, których celem działania jest dysponowanie środkami przeznaczonymi na modernizację energetyczną lub ochronę środowiska (na przykład Narodowy Funduszu Ochrony Środowiska i Gospodarki Wodnej) ${ }^{8}$.

\section{Zakres ochrony bezpieczeństwa energetycznego poprzez formy wsparcia bezpośredniego}

Wzrost wytwarzania energii ze źródeł odnawialnych spowodowany jest nałożeniem na pewne grupy podmiotów obowiązku wytwarzania energii z tych źródeł. Z obowiązkiem tym skorelowane są prawa tych podmiotów do określonej rekompensaty z tytułu poniesionych kosztów wytwarzania energii w stosunku do kosztów jej wytwarzania w źródłach tradycyjnych. W związku z tym dyrektywa 2009/28 nałożyła na państwa członkowskie UE obowiązek wspierania - w formie pomocy publicznej ${ }^{9}$ - wytwarzania energii elektrycznej ze źródeł

${ }^{8} \mathrm{Na}$ temat wsparcia energii odnawialnej w formach pośrednich zob. między innymi K. Tomczyk, Podatkowe stymulatory $i$ bariery rozwoju odnawialnych źródet energii $w$ Polsce, [w:] :] A. Walaszek-Pyzioł (red.), Wybrane węzłowe zagadnienia wspótczesnego prawa energetycznego, Kraków 2012, s. 355-367.

9 Szerzej zob. R. Zajdler, Pomoc publiczna dla odnawialnych źródet energii w świetle regulacji Unii Europejskiej, [w:] M. Królikowska-Olczak (red.), Studia z gospodarczego prawa Unii Europejskiej. Stan obecny i perspektywy rozwoju, Kraków 2004, s. 143-150. 
odnawialnych. W tym zakresie funkcjonują dwa systemy: kwotowy i cen sztywnych. System kwotowy opiera się na tak zwanych zielonych certyfikatach, których rolą jest wyrównanie różnicy w kosztach wytwarzania energii ze źródeł odnawialnych względem tradycyjnych. Wyrównanie tych kosztów jest możliwe poprzez nałożenie obowiązku nabycia określonej części całkowitego zużycia energii ze źródeł odnawialnych na wszystkich konsumentów. Z kolei system cen sztywnych (regulowanych) polega na nałożeniu na przedsiębiorstwa energetyczne (typowo dystrybucyjne) obowiązku nabywania energii elektrycznej wytworzonej ze źródeł odnawialnych przez rodzinnych producentów ${ }^{10}$.

W Polsce podstawą prawną w zakresie obowiązku wytwarzania energii ze źródeł odnawialnych jest treść art. 9a ustawy - Prawo energetyczne oraz rozporządzenie ministra właściwego do spraw gospodarki z dnia 18 października 2012 r. w sprawie szczegółowego zakresu obowiązków uzyskania i przedstawienia do umorzenia świadectw pochodzenia, uiszczenia opłaty zastępczej, zakupu energii elektrycznej i ciepła wytworzonych w odnawialnych źródłach energii oraz obowiązku potwierdzania danych dotyczących ilości energii elektrycznej wytworzonej w odnawialnym źródle energii: wskazuje wielkość energii koniecznej do wytworzenia w źródłach odnawialnych (dalej: rozporządzenie OZE) ${ }^{11}$.

Istota obowiązku wytworzenia energii ze źródeł odnawialnych polega na wytworzeniu tej energii w źródle odnawialnym (w wielkości określonej przez rozporządzenie OZE) w połączeniu z obowiązkiem pozyskania i przedstawienia do umorzenia ${ }^{12}$ świadectw pochodzenia lub (alternatywnie) z obowiązkiem zapłaty opłaty zastępczej (obliczonej zgodnie z przepisami ustawy - Prawo energetyczne) ${ }^{13}$. Podmiotowy wymiar omawianego obowiązku dotyczy czterech odrębnych grup podmiotów ${ }^{14}$. Inaczej mówiąc, obowiązek ten nałożony jest na następujące podmioty: 1) odbiorcę przemysłowego $\left.{ }^{15}, 2\right)$ przedsiębiorcę ener-

10 Z. Muras, Polityka UE i Polski w sprawie promocji odnawialnych źródet energii - różne rozwiązania, wspólny cel, „Biblioteka Regulatora” 2010, lipiec, s. 13.

11 Dz. U. z dnia 9 listopada 2012 r., poz. 1229.

12 Prawne zasady umarzania świadectw pochodzenia reguluje art. 9e ustawy - Prawo energetyczne.

${ }^{13}$ Szerzej zob. M.E. Górska, T. Krzywicki, Wspieranie odnawialnych źródel energii w Polsce, [w:] M. Wierzbowski, R. Stankiewicze (red.), Współczesne problemy prawa energetycznego, Warszawa 2010, s. 192.

${ }^{14}$ Szerzej na temat zakresu podmiotowego wskazanego obowiązku zob. Z. Muras, [w:] M. Swora, Z. Muras (red.), Prawo energetyczne. Komentarz, Warszawa 2010, s. 578-584.

15 Odbiorca końcowy, którego główną działalnością gospodarczą jest działalność w zakresie: a) wydobywania węgla kamiennego lub rud metali nieżelaznych, b) produkcji wyrobów z drewna oraz korka z wyłączeniem produkcji mebli, c) produkcji papieru i wyrobów z papieru, d) produkcji chemikaliów i wyrobów chemicznych, e) produkcji wyrobów z gumy i tworzyw sztucznych, f) produkcji szkła i wyrobów ze szkła, g) produkcji ceramicznych materiałów budowlanych, h) produkcji metali, i) produkcji elektrod węglowych i grafitowych, styków i pozostałych elektrycznych wyrobów węglowych i grafitowych, j) produkcji żywności. Ustawa - Prawo energetyczne, art. 3 pkt $20 \mathrm{f}$. 
getycznego $^{16}, 3$ ) odbiorcę końcowego ${ }^{17}$ oraz 4) towarowy dom maklerski ${ }^{18}$. Nierozerwalną częścią realizacji opisanej powyżej zasady wsparcia bezpośredniego jest obowiązek określonych podmiotów zakupu energii wytworzonej w źródłach odnawialnych. Zgodnie z art. 9a ust. 6 ustawy - Prawo energetyczne podmiotem zobowiązanym do zakupu energii wytworzonej w źródłach odnawialnych jest sprzedawca z urzędu. Obowiązek dotyczy źródeł odnawialnych przyłączonych do sieci dystrybucyjnej lub przesyłowej, które znajdują się na terenie obejmującym obszar działania tego sprzedawcy, a energia oferowana jest przez przedsiębiorstwo energetyczne, które uzyskało koncesję na jej wytwarzanie lub zostało wpisane do rejestru działalności regulowanej (działalność gospodarcza w zakresie wytwarzania biogazu rolniczego lub wytwarzania energii elektrycznej z biogazu rolniczego). Omawiany zakup odbywa się po średniej cenie sprzedaży energii elektrycznej w poprzednim roku kalendarzowym. Zatem obowiązek zakupu energii wytworzonej w źródłach odnawialnych został nałożony na przedsiębiorstwo energetyczne posiadające koncesję na obrót paliwami gazowymi lub energią elektryczną, świadczące usługi kompleksowe odbiorcom paliw gazowych lub energii elektrycznej $\mathrm{w}$ gospodarstwie domowym, niekorzystającym z prawa wyboru sprzedawcy.

Podsumowując istotę wsparcia bezpośredniego w sektorze energii odnawialnej należy podkreślić, że system ten będzie skuteczny jedynie wówczas, jeżeli zasady wsparcia będą określane w perspektywie długookresowej, z jednoczesnym określeniem okresu wygasania dla danych technologii i jednostek ${ }^{19}$.

\section{Zakres ochrony bezpieczeństwa energetycznego w formie zapewnienia pierwszeństwa dostępu OZE do sieci}

Rozwój całego sektora energetycznego oparty jest na procesach liberalizacyjnych, których celem jest wprowadzenie konkurencji w jego obszarze. Dlatego przepisy prawa energetycznego zapewniają dostęp do sieci infrastrukturalnej

${ }^{16}$ Podmiot prowadzący działalność gospodarczą w zakresie: a) wytwarzania, przetwarzania, magazynowania, przesyłania, dystrybucji paliw albo energii lub obrotu nimi albo b) przesyłania dwutlenku węgla. Ibidem, art. 3, pkt 12.

${ }^{17}$ Odbiorca dokonujący zakupu paliw lub energii na własny użytek; do własnego użytku nie zalicza się energii elektrycznej zakupionej w celu jej zużycia na potrzeby wytwarzania, przesyłania lub dystrybucji energii elektrycznej. Ibidem, art. 3, pkt 13 a.

18 Spółka akcyjna albo spółka z ograniczoną odpowiedzialnością z siedzibą na terytorium Rzeczypospolitej Polskiej, prowadząca działalność maklerską w zakresie obrotu towarami giełdowymi. Ustawa z dnia 26 października 2000 r. o giełdach towarowych (tekst jedn. Dz. U. z 2010 r., nr 48, poz. 284 z późn. zm.), art. 2, pkt 8.

19 Z. Muras, Systemy wsparcia bezpośredniego źródel odnawialnych i kogeneracyjnych - wczoraj, dziś, jutro, [w:] A. Walaszek-Pyzioł (red.), op. cit., s. 351. 
wszystkim zainteresowanym podmiotom, które zamierzają wykonywać działalność w sektorze energetycznym (tak zwana zasada dostępu osób trzecich, inaczej TPA: third party access $)^{20}$. Zgodnie z dyrektywą 2009/28 zasada dostępu dotyczy również źródeł odnawialnych, z tym jednak szczególnym rozwiązaniem, że jest to dostęp uprzywilejowany, co wynika przede wszystkim z treści art. 16 ust. 2 pkt b dyrektywy OZE, który stanowi, że „państwa członkowie zapewniają również priorytetowy dostęp do systemu sieciowego dla energii elektrycznej wytwarzanej z odnawialnych źródeł energii”. Oznacza to, że rozwiązania unijne promują pierwszeństwo dostępu źródeł odnawialnych do sieci, co potwierdza ponadto pkt 61 preambuły do dyrektywy 2009/28, który wskazuje na obowiązek państw członkowskich takiego ukształtowania krajowych ram prawnych, aby zapewnione było jak najszybsze przyłączenie nowych instalacji OZE. Jedynie wymogi odnoszące się do zachowania niezawodności i bezpieczeństwa sieci uzasadniają odstąpienie od wskazanej zasady uprzywilejowanego dostępu do sieci.

Przepisy ustawy - Prawo energetyczne wprowadzają czteroetapową procedurę przyłączenia do sieci, na którą składają się: 1) uzyskanie warunków przyłączenia do sieci elektroenergetycznej, 2) zawarcie umowy o przyłączenie do sieci elektroenergetycznej, 3) zawarcie umowy o przesył lub dystrybucję oraz 4) zawarcie umowy o sprzedaż energii. Dokładny zakres każdego z etapów wyznaczają treści art. 5 i art. 7 ustawy - Prawo energetyczne oraz rozporządzenie OZE, które reguluje wielkość energii koniecznej do wytworzenia w źródłach odnawialnych.

Zgodnie z art. 7 ust. 1 ustawy - Prawo energetyczne

[...] przedsiębiorstwo energetyczne zajmujące się przesyłaniem lub dystrybucją paliw gazowych lub energii jest obowiązane do zawarcia umowy o przyłączenie do sieci z podmiotami ubiegającymi się o przyłączenie do sieci, na zasadzie równoprawnego traktowania, jeżeli istnieją techniczne i ekonomiczne warunki przyłączenia do sieci i dostarczania tych paliw lub energii, a żądający zawarcia umowy spełnia warunki przyłączenia do sieci i odbioru. Jeżeli przedsiębiorstwo energetyczne odmówi zawarcia umowy o przyłączenie do sieci, jest obowiązane niezwłocznie pisemnie powiadomić o odmowie jej zawarcia Prezesa Urzędu Regulacji Energetyki i zainteresowany podmiot, podając przyczyny odmowy.

Warunki - o których stanowi cytowany artykuł - udzielane są zawsze na wniosek podmiotu zainteresowanego (przyłączeniem instalacji OZE do sieci). Treść tego wniosku oraz treść udzielonych warunków determinowane są treścią $\S 7$ i § 8 Rozporządzenia Ministra Gospodarki z dnia 4 maja 2007 r. w sprawie szczegółowych warunków funkcjonowania systemu elektroenergetycznego ${ }^{21}$. Na podstawie wspomnianych warunków zostaje zawarta umowa o przyłączenie do sieci, której minimalne elementy określa art. 7 ust 2 ustawy - Prawo energetyczne. W tym zakresie należy zwrócić uwagę, że od wejścia w życie „małe-

${ }^{20} \mathrm{Na}$ temat liberalizacji sektorów infrastrukturalnych i zasady TPA zob. szerzej M. Szydło, Regulacja sektorów infrastrukturalnych jako nowa funkcja państwa w gospodarce, Torun 2005, passim.

${ }^{21}$ Dz. U. nr 93, poz. 623. 
go trójpaku energetycznego" obowiązkowym elementem umowy o przyłączenie do sieci jest harmonogram przyłączenia, co należy ocenić pozytywnie z punktu widzenia ochrony praw podmiotów ubiegających się o przyłączenie do sieci. Trzecim etapem procedury przyłączenia do sieci jest zawarcie umowy o przesył lub dystrybucję, której wymagane minimalne elementy określa art. 5 ust. 2 pkt 2 ustawy Prawo energetyczne. Ostatnim etapem, który kończy proces uzyskania dostępu do sieci jest zawarcie umowy o sprzedaż energii, której minimalne elementy określa art. 5 ust. 2 pkt 1 ustawy Prawo energetyczne, a podmiotem zobowiązanym do jej zawarcia - jak wynika z rozważań dotyczących form wsparcia bezpośredniego - jest sprzedawca $z$ urzędu.

Podsumowując opisaną powyżej w sposób ogólny procedurę przyłączenia do sieci - w kontekście zapewnienia dostępu uprzywilejowanego dla przyłączenia źródła OZE - trzeba wskazać, że obowiązujące przepisy prawa energetycznego nie pozwalają na pełną realizację tej zasady w warunkach krajowych. Wynika to głównie z tego, że przepisy wprost nie określają maksymalnego terminu zawarcia umowy o przyłączenie do sieci. Należy przyjąć, że do zawarcia umowy dojdzie, jeżeli strony umowy (to jest podmiot składający wniosek o przyłączenie oraz operator sieci) dojdą do porozumienia co do treści wszystkich obowiązkowych elementów umowy. Oznacza to, że mogą one prowadzić negocjacje w tym zakresie bez ograniczonego terminu ich trwania. Jeżeli nie zakończą się one w terminie obowiązywania warunków o przyłączenie, to jest w ciągu 2 lat, to operator sieci przestaje być zobowiązany do zawarcia umowy o przyłączenie do sieci. Jest to rozwiązanie odbiegające od wyznaczonej dyrektywą OZE zasady uprzywilejowania dostępu do sieci i w kontekście rozwoju energii wytwarzanej w odnawialnych źródłach energii, która ma sprzyjać zapewnieniu bezpieczeństwa energetycznego, należy je ocenić krytycznie.

\section{Zakres ochrony bezpieczeństwa energetycznego poprzez wsparcie energetyki prosumenckiej}

Przepisy wspierające rozwój energii ze źródeł odnawialnych wytwarzanej przez osoby fizyczne i zużywaniu jej na ich własne potrzeby są nowymi przepisami w ustawie - Prawo energetyczne. W związku z tym na początku należy określić ich istotę, która polega na tym, że rozwój energetyki prosumenckiej związany jest z promowaniem wytwarzania energii elektrycznej w mikroinstalacji przez osobę fizyczną niebędącą przedsiębiorcą w rozumieniu ustawy o swobodzie działalności gospodarczej ${ }^{22}$, a jej sprzedaż nie jest działalnością gospodarczą definiowana przez art. 2 tej ustawy.

22 Ustawa $\mathrm{z}$ dnia 2 lipca 2004 r. o swobodzie działalności gospodarczej, tekst jedn. Dz. U. z 2013 r., poz. 672. 
Analizując przepisy dotyczące wytwarzania energii odnawialnej w mikroinstalacji, można stwierdzić, że są one skuteczne w zakresie promocji wytwarzania energii przez konsumentów z punktu widzenia czterech najważniejszych zasad.

Po pierwsze, zasady obowiązku zakupu energii wytworzonej w mikroinstalacji. Podmiotem zobowiązanym do zakupu tej energii jest sprzedawca z urzędu. Zgodnie z treścią art. 9v - ustawy Prawo energetyczne:

energię elektryczną wytworzoną w mikroinstalacji przyłączonej do sieci dystrybucyjnej znajdującej się na terenie obejmującym obszar działania sprzedawcy z urzędu i oferowaną do sprzedaży przez osobę fizyczną jest obowiązany zakupić ten sprzedawca. Zakup tej energii odbywa się po cenie równej $80 \%$ średniej ceny sprzedaży energii elektrycznej w poprzednim roku kalendarzowym ${ }^{23}$.

Po drugie, zasady opłaty za przyłączenie do sieci. Na wstępie należy wskazać, że jest ona preferencyjna, bowiem zgodnie z art. 7 ust. 8 pkt 3 ustawy - Prawo energetyczne

[...] za przyłączenie źródeł współpracujących z siecią oraz sieci przedsiębiorstw energetycznych zajmujących się przesyłaniem lub dystrybucją paliw gazowych lub energii pobiera się opłatę ustaloną na podstawie rzeczywistych nakładów poniesionych na realizację przyłączenia, z wyłączeniem: a) odnawialnych źródeł energii o mocy elektrycznej zainstalowanej nie wyższej niż 5 MW oraz jednostek kogeneracji o mocy elektrycznej zainstalowanej poniżej 1 MW, za których przyłączenie pobiera się połowę opłaty ustalonej na podstawie rzeczywistych nakładów, b) mikroinstalacji, za której przyłączenie do sieci dystrybucyjnej elektroenergetycznej nie pobiera się opłaty.

Po trzecie, zasady odmowy dostępu do sieci. Zgodnie z art. 9 ust. $8 \mathrm{~d}^{2}$ ustawy - Prawo energetyczne

[...] w przypadku gdy przedsiębiorstwo energetyczne zajmujące się przesyłaniem lub dystrybucją energii elektrycznej odmówi przyłączenia do sieci odnawialnego źródła energii z powodu braku technicznych warunków przyłączenia wynikających z braku niezbędnych zdolności przesyłowych sieci w terminie proponowanym przez podmiot ubiegający się o przyłączenie odnawialnego źródła energii przedsiębiorstwo energetyczne określa planowany termin oraz warunki wykonania niezbędnej rozbudowy lub modernizacji sieci, a także określa termin przyłączenia.

\section{Ponadto, zgodnie $\mathrm{z}$ art. 9 ust. $8 \mathrm{~d}^{3}$ ustawy - Prawo energetyczne}

[...] w przypadku braku technicznych lub ekonomicznych warunków przyłączenia w zakresie mocy przyłączeniowej określonej we wniosku o określenie warunków przyłączenia odnawial-

${ }^{23}$ Odrębna kwestię stanowi pytanie, czy słuszne jest rozwiązanie w ramach którego, prawu (decyzja fakultatywna) wytwarzania energii w źródłach odnawialnych towarzyszy obowiązek jej zakupu jedynie w obszarze wytwarzania energii w mikroinstalacji. Dyskusję na ten temat zob. szerzej M. Koszowski, Polityka wobec odnawialnych źródet energii - wczoraj, dziś, jutro - pomoc, wsparcie, konkurencja, [w:] T. Długosz (red.), Ochrona konkurencji i konsumentów w prawie sektorów infrastrukturalnych, Kraków 2012, s. 86-87. 
nego źródła energii, przedsiębiorstwo energetyczne zajmujące się przesyłaniem lub dystrybucją energii elektrycznej powiadamia podmiot ubiegający się o przyłączenie o wielkości dostępnej mocy przyłączeniowej, dla jakiej mogą być spełnione te warunki. Jeżeli podmiot ten, w terminie 30 dni od dnia otrzymania powiadomienia: 1) wyraził zgodę na taką wielkość mocy przyłączeniowej, przedsiębiorstwo to wydaje warunki przyłączenia; 2) nie wyraził zgody na taką wielkość mocy przyłączeniowej, przedsiębiorstwo to odmawia wydania warunków przyłączenia.

Po czwarte, zasady przyłączenia do sieci. Zgodnie z art. 9 ust. $8 \mathrm{~d}^{4}$ ustawy - Prawo energetyczne

[...] w przypadku gdy podmiot ubiegający się o przyłączenie mikroinstalacji do sieci dystrybucyjnej jest przyłączony do sieci jako odbiorca końcowy, a moc zainstalowana mikroinstalacji, o przyłączenie której ubiega się ten podmiot, nie jest większa niż określona w wydanych warunkach przyłączenia, przyłączenie do sieci odbywa się na podstawie zgłoszenia przyłączenia mikroinstalacji, złożonego w przedsiębiorstwie energetycznym, do sieci którego ma być ona przyłączona, po zainstalowaniu odpowiednich układów zabezpieczających i układu pomiarowo-rozliczeniowego. W innym przypadku przyłączenie mikroinstalacji do sieci dystrybucyjnej odbywa się na podstawie umowy o przyłączenie do sieci. Koszt instalacji układu zabezpieczającego i układu pomiarowo-rozliczeniowego ponosi operator systemu dystrybucyjnego elektroenergetycznego.

Wprowadzone „małym trójpakiem energetycznym” przepisy ustawy - Prawo energetyczne $\mathrm{w}$ zakresie wspierania energetyki prosumenckiej należy ocenić pozytywnie, zwłaszcza w kontekście treści dyrektywy OZE w zakresie zwolnienia „najmniejszych” odnawialnych źródeł energii z oceny z punktu widzenia możliwości technicznych lub ekonomicznych dla ich przyłączenia. Ponadto, koszty instalacji układu zabezpieczającego i układu pomiarowo-rozliczeniowego ponoszone są przez operatora systemu elektroenergetycznego, a nie przez osobę fizyczną.

\section{Uwagi końcowe}

Nie ulega wątpliwości, że obszerne przepisy prawa energetycznego wprowadzają szereg rozwiązań mających na celu ochronę bezpieczeństwa energetycznego w całym sektorze energetycznym, w tym również poprzez zabezpieczenie dostaw energii wytwarzanej w źródłach odnawialnych. Podsumowując ogólnie powyższe rozważania warto wskazać, że podstawowym rozwiązaniem prawnym gwarantującym dostawę energii wyprodukowanej w źródłach odnawialnych jest publicznoprawny obowiązek wytwarzania tej energii nałożony na określone grupy podmiotów. Samo nałożenie obowiązku wytwarzania energii w drodze ustawy należy ocenić pozytywnie, jednakże - jak wynika z powyższych rozważań - nieprecyzyjne są przepisy w zakresie dostępu źródeł odnawialnych do sieci. Jest to bez wątpienia jedna z najpoważniejszych barier prawnych w zakresie skutecznego rozwoju sektora źródeł odnawialnych. Pozytywnie jednak należy ocenić 
najnowsze rozwiązania ustawy - Prawo energetyczne w zakresie wspierania energetyki prosumenckiej. W tym zakresie na szczególne uwzględnienie zasługuje nałożenie na sprzedawcę z urzędu obowiązku zakupu energii wytworzonej w mikroinstalacji i stosowanie opłat preferencyjnych z tytułu dostępu do sieci. Jednak ogólny wniosek jest taki, że prawna ochrona (wynikająca z ustawy - Prawo energetyczne) bezpieczeństwa energetycznego w sektorze energii odnawialnej nie jest wystarczająca. Po pierwsze dlatego, że wciąż jest brak pełnej implementacji dyrektywy 2009/28, a nowelizacja w formie „małego trójpaku energetycznego" stanowi jedynie początek procesu dostosowywania krajowych przepisów dotyczących energii odnawialnej do wymogów przyjętych przez UE. Po drugie, ponieważ obowiązujące przepisy ustawy Prawo energetyczne - nie zapewniają pełnej i skutecznej ochrony rozwoju sektora źródeł odnawialnych, nawet po nowelizacji ustawy „małym trójpakiem energetycznym”. 